\title{
Entrepreneurship through Bricolage. A Study of Displaced Entrepreneurs at Times of War and Conflict ${ }^{1}$.
}

\author{
Caleb Kwong, University of Essex, UK \\ Cherry Cheung, London South Bank University, UK \\ Humera Manzoor, Kohat University of Science and Technology, Pakistan \\ Mehboob Ur Rashid, University of Peshawar, Pakistan
}

\begin{abstract}
War and conflict brings about adverse changes for those who are displaced. How do entrepreneurial individuals respond to such adversity to either set-up, or continue with their existing entrepreneurial endeavours that would improve their own livelihood or that of others who have been affected? Whilst previous studies have found local knowledge, networks and resources to be crucial in the development of ventures in the war and conflict context, alienation from mainstream society within the host location often means that to succeed, those who are displaced require alternative strategies and approaches. Through examining the entrepreneurship ventures of six internally displaced entrepreneurs in Pakistan, our study identifies that entrepreneurial individuals find different ways to adapt to the new order, with both internal and external bricolage becoming the key strategies deployed to either re-establish their previous business(es) or to develop new endeavour(s) in the host location. To compensate for lack of local knowledge, networks and resources, we found that entrepreneurs followed closely their previous paths in their bricolage attempts, relying on reconfigurations of their preexisting competencies, as well as utilising pre-established and clandestine networks.
\end{abstract}

Keywords: entrepreneurship, bricolage, war and conflict, displaced population

\section{Acknowledgement}

The authors would like to acknowledge the contribution of Abdur Redman, from the Institute of Management Science, Kohat University of Science and Technology, Pakistan, for being a gatekeeper who facilitated this research. We would also like to thank the participants of the Migration and Diaspora Entrepreneurship Conferences, held at the University of Bremen, Germany, for their insightful feedback on an earlier draft of this paper.

\footnotetext{
${ }^{1}$ To cite: Kwong, C., Cheung, C., Manzoor, H. and Rashid, M. (Forthcoming) Entrepreneurship through Bricolage. A Study of Displaced Entrepreneurs at Times of War and Conflict. Entrepreneurship and Regional Development.
} 


\section{Introduction}

War and conflict are a major cause of paucity, destroying economic activities and livelihoods, and creating poverty on an endemic scale (MacSweeney, 2008). An inevitable consequence of war and conflict is the emergence of a displaced population. A displaced population typically comprises refugees (across borders), internally displaced persons (within borders) and asylum seekers (applied for but case not yet concluded). The term 'displaced population' refers to somebody who has been 'forced to flee his or her country because of persecution, war, or violence. The person has a well-founded fear of persecution for reasons of race, religion, nationality, political opinion or membership of a particular social group. Most likely, they cannot return home or are afraid to do so' (UNHCR, 2017, p.1). The notion of a displaced population was first defined in the 1950 Geneva convention, with the 1967 Protocol expanding the scope of the Convention to the wider displacement problem. According to the UNHCR in 2016 , there are $14.4 \mathrm{~m}$ refugees and $38 \mathrm{~m}$ internally displaced persons across the world, the majority of whom are based in developing nations. The displaced population tends to include some of the most marginalised social groups in any society, facing economic and social isolation and enduring poverty (Turner, 2010). The need to support them is pressing. Traditionally, the 'relief' form of support is deployed as the first line of approach towards poverty reduction, but this is often criticised for its lack of sustainability and for developing a dependency mindset which further hinders future progress (Ellis and Barakat, 1996). Refusing to rely on hand-outs, many from displaced populations actively seek employment in the host location. This, however, remains challenging due to differences in language, culture, styles of work, discrimination, compatibility of qualifications, and lack of demand for the professions of prior specialisations.

Entrepreneurship presents a potential alternative job choice for the displaced population in overcoming the structural employment challenges impeding their personal advancement in the 
host location (Harima and Freiling, 2016). Entrepreneurship offers more control in the workplace environment, enables work to be tailored, ensures that skills are utilised and allows work to reflect personal interests. It can also enable some of the language and social communication difficulties to be bypassed through careful selection of partners and employees. A number of existing studies have already explored the role of entrepreneurship in the contexts of war and conflict, and found that entrepreneurship can indeed create positive economic and social impacts on those affected by them (Bullough et al., 2015; Cheung and Kwong, 2017). However, most of these studies do not focus on the factor of displacement, which creates a unique context for those affected and brings in additional barriers to those intending to develop a business venture. Cheung and Kwong (2017), for instance, highlight the role of local knowledge, networks and at-hand resources in the development of business ventures during warfare, all of which are hard for displaced persons to acquire or develop due to their limited time within the host location. To make the problem even worse, the rapid nature of their departure often means that they have little time to prepare for life in the host location, leaving their capital and valuable belongings behind that could be crucial for restarting life in the host location. They also face considerable challenges in establishing new social networks in the host country, while previous networks may have become obsolete (Bizri, 2017; Harima and Freiling, 2016). This suggests that those who are displaced may require a different strategy towards business start-up and development, in order to overcome some of their inherited limitations mentioned above.

Within the entrepreneurship literature, bricolage is increasingly being recognised as an important strategy to tackle resource constraints in penurious contexts (Garud and Karnøe 2003; Stinchfield, Nelson, and Wood 2013; Baker and Nelson 2005; Baker, Miner, and Eesley 2003). Fisher (2013), for instance, places bricolage alongside causation and effectuation as the three main strategies that entrepreneurs deployed in their business endeavours. The term 
'bricolage' was first coined by Levi-Strauss $(1967,17)$ as "making do with whatever is at hand", to contrast with the strategy of optimisation involving the acquisition of high quality resources that have proven capabilities for the specific application for which the resources are intended (Desa \& Basu, 2013). It involves the 'redeployment of discarded, disused, or unwanted resources-at-hand, be it physical artefacts, skills or knowledge, in ways different from those for which they were originally intended' (Jayawarna, Jones, and MacPherson, 2014). Such reconfiguration requires innovative thinking, where bricoleurs refuse to accept the established limitations imposed upon the resources by others, and stretch their resources in novel ways to create new purposes and directions (Baker and Nelson, 2005).

The application of bricolage is likely to be particularly relevant in the contexts of war and conflict where lack of resources is of general concern, and where unpredictable contextual changes often create unexpected opportunities that entrepreneurial individuals can capture to great effect (Cheung and Kwong, 2017). Nevertheless, what are these at-hand resources that entrepreneurial individuals amongst the displaced population could augment and reconfigure in the first place? With limited connection to the host location, these resources would have to come from elsewhere. Previous studies have suggested that entrepreneurs would go further in searching for these resources, although the high risk associated with the war and conflict contexts could make such searches prohibitively costly and ineffective (Lee and Venkataraman, 2006). Alternatively, deprivation could push enterprising individuals to search deeper from within, through reflecting upon the path they have undertaken within their life course with greater scrutiny and persistency (Shane, 2000). This could enable them to realise a previously untapped repertoire of resources and competencies that would facilitate their attempt at bricolage. These are very important questions because only when the resources and strategies that the displaced entrepreneurs deployed have been identified can their effectiveness be evaluated, and also support provisions be identified. 
In this study we focus on entrepreneurial individuals who were already involved in businesses prior to displacement, and explore how bricolage is deployed by them in the face of displacement challenges. The research questions are as follows:

- What are the types of resources that the displaced entrepreneurs can utilise in order to revive their entrepreneurial career?

- What is the role of bricolage in the resource mobilisation process and in the development of entrepreneurial ventures amongst displaced entrepreneurs?

- How does the implementation of bricolage affect the nature and outcomes of their entrepreneurial endeavours?

In the sections that follow, we first examine the theoretical framework of bricolage and within it, the different resource mobilisation strategies. We then turn our focus to the particular context of conflict and our specific cases, as well as the methodology adopted. After revealing the findings, we discuss the role of bricolage in the venture development of entrepreneurs. We finally conclude our study, where managerial and policy implications are also discussed.

\section{Literature Review}

In the context of resource constraints, bricolage, or the making-do with resources-at-hand to tackle new entrepreneurial opportunities for which the resources were not originally intended (Baker and Nelson, 2005), emerges as one of the most viable resource utilisation strategies (Fisher 2012). The process of bricolage places great emphasis on the cognitive framework of the bricoleurs in the opportunity recognition and pursuance process (Fisher, 2012; Desa and Basu, 2013; Tracey and Philips, 2007; Desa 2012). It requires entrepreneurs to challenge limitations set out by existing resource constraints and industry standards, practices, and regulations (Desa, 2012; Weick, 1998), and to 'creatively reinvent' (Rice and Roger, 1980), through the repackaging, transposing and recombining of undervalued, slack or discarded 
resources, be it materials, labour, skills, practices, assets or networks that are either at-hand or can be cheaply acquired (Baker and Nelson, 2005). According to Baker and Nelson (2005), these resources-at-hand can be categorised into five domains, including the three inputs of material, skills and labour, as well as the customers and regulatory and institutional domains. Internal bricolage involves a great deal of scavenging (Hewerdine, Rumyantseva and Welch, 2014,). Literature often portrays bricoleurs as magicians turning scraps into treasures, as illustrated by Garud and Karnoe's (2003) study of the Danish wind turbine industry, or Gibbert and Scranton's (2009) study on the post-war jet engine development by the impoverished German BMW that outperformed their wealthy American counterpart, GM. As war and conflict is a form of penurious environment, it is expected that creative utilisation of resourcesat-hand would play a major role in the process.

The existing literature has categorised bricolage into different forms, all of which involve the reconfiguration process highlighted above, but also involve different at-hand resource domains and external actors (see Table 1 for further elaboration).

*** Insert Table 1 about here ${ }^{* * *}$

\section{Opportunities and challenges in deploying bricolage in the context of displacement}

It is not difficult to see that the logic of bricolage can easily be applied to the context of displacement. Resource paucity in the context of war and conflict indicates that bricolage could play a significant role as a cost-effective resource mobilisation strategy in enabling displaced entrepreneurs to repair the damages caused to them and their businesses by war and conflict. Nevertheless, as an emerging theory that has become prominent in the past decade (Nelson and Baker, 2005), many aspects of the theory, in particular its boundary conditions, have not yet been thoroughly explored. There are challenges in implementing bricolage in the context of displacement that are yet to be fully understood. First, the resource context of displacement is 
different from other forms of penurious environment, and second, the personal motives of the displaced entrepreneurs may be very different from those who are already operating in the penurious environment.

First, previous studies have explored the use of bricolage in various penurious environment contexts, and found a number of factors to be facilitative and hindrance to the adoption of bricolage. In different penurious environments, the different resource availability requires different forms of bricolage. For instance, studies have suggested that collaborative bricolage would be most crucial in social enterprises, charities and non-profit organisations because of the non-competitive, mutually beneficial co-creation discourse that is prevalent within the sector (Kwong et al., 2017; Tasavori et al., forthcoming; Lewis, 2013; Huybrechts et al., 2017; de Bruin et al., 2017), while in art and cultural organisations, bricolage often surrounds the utilisation of the artists' personalities, identities and visions, but pragmatically, also evolve around the deployment of resources within the community, network of stakeholders and other social connections (Stinchfield et al., 2013; Preece, 2014). In the fields of science engineering and for craftsmanship, in contrast, studies on bricolage are often connected to the notion of process innovation, and in particular, how to improve the efficiency of the ways in which existing resources are being utilised (Stinchfield et al., 2013, Garud and Karnoe, 2003, Gibbert and Scranton, 2009). Therefore, understanding the type of bricolage that is most applicable in dealing with resource paucity in displacement is crucial.

A study relevant to our context is by Cheung and Kwong (2017), looking at how Chinese entrepreneurs in World War II survived and developed their business ventures, under warfare and foreign occupation. The study found local bricolage to be crucial to such endeavours, and the bricolage attempts involved the utilisations of local market knowledge, norms and sectoral knowledge, as well as local networks. However, while equally affected by war and conflict, the local resources and knowhow that those who remained at home possessed are precisely 
what the displaced entrepreneurs lacked in the host environment. Therefore, if the displaced entrepreneurs are to develop business ventures through bricolage, different sets of resources and skillsets would have to be deployed.

We argue that the context of displacement creates a very specific situation in which a theoretical extension from the existing bricolage theory is required. Whetten (1989) emphasises the importance of both comprehensiveness and parsimony in the development of theory in business and management research, and it would be important to understand, in the context of displacement, the factors that stand out as crucial for displaced entrepreneurs to continue with their entrepreneurial journey. With the call for greater emphasis on the utility for practice (Corley and Gioia, 2011), integrating empirical displacement research into the existing bricolage framework is important in advancing the scope of knowledge, and could offer a different perspective in the wider debate of displacement supports (Strang and Ager, 2010). To do so, we need to understand, firstly, the specificities of the penurious environment of displacement; second, the specific resources that displaced entrepreneurs could have deployed in the context that they faced, and whether these were internally prepossessed or acquired externally through different means; and, finally, how these resources are utilised and reconfigured for the purpose of bricolage.

From the literature of displacement, it is apparent that displaced entrepreneurs face some significant resources challenges (Hobfoll, 2001), which could affect the extent to which the strategy of bricolage can be deployed. Unlike in other penurious environments, the entrepreneurs often face a rapid deterioration in their personal circumstances in the contexts of war and conflict (Cheung and Kwong, 2017). Many displaced entrepreneurs have suffered from personal possessions being stolen, confiscated or destroyed, premises illegally occupied, or resources simply left behind due to the immobile nature of property and other physical resources (Assaf and El-Fil, 2000), leaving them with few resources at their disposal. To 
overcome this, the existing literature has suggested that bricoleurs can apply broad sets of rudimentary skills and craft knowledge that they pre-possessed, to defy and stretch the defined limitations of their limited array of resources to create new products and services (Ronkko, Peltonen and Arenius, 2014). However, whilst displaced entrepreneurs may have accumulated life skills, there is often a mismatch with the host environment (Sinclair, 2001). Different market demands, preferences, industry standards, norms and operational processes could mean that their prior competencies are not fully transferable (Duvander, 2001; Krahn et al., 2000; Ryan et al., 2008). Furthermore, their lack of familiarity with the institutional context and regulatory environment could be the stumbling block (Cheung and Kwong, 2017; Krahn et al., 2000). Therefore, it is unclear from the existing literature the type of resources that would be crucial for bricolage in the context of displacement.

Nevertheless, whilst individuals may experience resource losses as a result of displacement, they could regain new ones in the host environment (Ryan et al., 2008). Hobfoll's conservation of resources theory (2001) highlights two strategies that can be used: resource replacement and resource substitution. While direct resource replacement would be difficult in the displacement context due to costs, the literature on immigrant entrepreneurship suggests that enterprising individuals could develop substitutes from the newly found resources existing within the host's enterprise ecosystem (Habbershon, 2006). Such replacement or substitution could allow new resources to be deployed in overcoming personal and environmental constraints in associating with the new host environment (Ryan et al., 2008). These substitutions that they develop in the host country can sometimes be advantageous, as they can be more aligned with the requirements of the host environment, which enables these entrepreneurs to become more embedded (Portes and Sensenbrenner, 1993). However, we know very little of the types of resources to be potentially utilised, and how bricolage, or other strategies, can be deployed for their mobilisation. Furthermore, as the resources that had been replaced or substituted would 
not be identical to the resources that the displaced entrepreneurship previously possessed or utilised, the nature of the eventual venture would likely be different from how it was previously. Previous studies on bricolage have suggested that the utilisation of external resources could often have a significant influence on the outcome of bricolage, with the entrepreneurs potentially losing control in terms of the nature of the business, target market, and other significant strategic directions (Kwong et al., 2017). As we are unsure of the external resources that can be deployed in the context of displacement, the impact and influence on external resources on the nature and outcomes of these ventures is unclear from the bricolage literature.

Second, while displaced entrepreneurs may be constrained by the reality of resource paucity, there are other objective conditions governing their entrepreneurial behaviours. The literature on displacement has suggested that the economic activities that displaced individuals choose to embark upon is largely determined by their personal goals and motives (Ryan et al., 2008). Hofboll's (2001) theory of conservation of resources makes the basic assumption that individuals, in the context of displacement or other stressful situations, often strive to protect and retain the status quo in order to maintain their psychological wellbeing, and that such a protective desire is likely to have a downstream impact on how the existing resources will be utilised (Hobfoll, 2001). Ryan et al., (2008) further elaborate that such a protective desire often goes beyond the attempt to restore monetary parity, and extends to other personal needs, such as psychological comfort, that cannot be easily quantified. As the displaced persons will inevitably compare their new environment to what they have left behind (Halbesleben, et al., 2014), they often first look to replicate the conditions prior to displacement, rather than starting completely afresh (Carey-Wood et al., 1995). Studies have suggested that, in the context of unexpected turbulent events such as natural disaster, individuals take defensive future steps by investing their existing resources towards protecting what they previously had (Halbesleben and Bowler, 2007; Benight et al., 1999). This suggests that displaced entrepreneurs often 
consider ways to balance economic rationality with the restoration of their previous lives prior to conflict, which could mean that, subsequently, their bricolage attempts are likely to be different and potentially more rigid and goal-driven when compared to those starting up a business in other penurious environments. The focus on restoration could mean that displaced entrepreneurs may prioritise the replication of previous business, even when the economic case for doing so may not be particularly strong. This could have an impact on the performance outcomes of the ventures.

\section{Methodology}

\section{Data collection}

In the penurious context of displacement which the few existing studies have examined (Bizri, 2017; Wauters and Lambrecht, 2006; 2008), a qualitative multiple case study design was pursued to extend theory into this context (Graebner, Martin \& Roundy, 2012) and to generate new theoretical and managerial insights (Yin, 2012). Multiple cases permit replication logic (Yin, 2012) and lead to more robust, generalizable theory than a single case (Eisenhardt \& Graebner, 2007). Such as approach is consistent with some previous studies that studied entrepreneurship in a crisis situation, including Doern (2016), Doern (2017) and Cheung and Kwong (2017). Six entrepreneurs were selected and interviewed from a convenience sample (Saunders, Lewis, \& Thornhill, 2009). The difficulties in finding suitable informants for the restricted context of conflict (Goodhand, 2000) means that we had to restrict the number of entrepreneurs studied, although the size of our sample is consistent with Eisenhardt and Graebner (2007), who suggest that the number of cases in a qualitative research should be between 4 and 10, as fewer cases limits the possibility of generalisation, and more cases complicates the analysis. 
The data are gathered from war and conflict situations that took place in Pakistan, focusing on internally displaced persons that were forced to leave the Federally Administered Tribal Area (FATA) and move to a safer place due to the armed conflict between the Taliban and the Pakistan armed forces (Figure 1). The Taliban began to enter the area in the early 2000s, and over the years from 2004-2008, the army-led operations in the region caused the largest internal displacement in the country's history. By 2016, there were more than 1.8 registered internally displaced persons (IDPs) (Weinbaum, 2017). While 146,485 families and around 880,000 people were in camps (UNHCR, 2016), many shunned them due to both poor conditions and being against the norms of the "Pakhtun" community which largely forbids their women to be seen by other men (Weinbaum, 2017; Abu-Lughod, 2002). Our study focuses on displaced individuals who lived with the host population away from the camps, and had previous experience in business, either as an entrepreneur or as an apprentice. These entrepreneurs all faced considerable challenge in the host location, which is outlined in the results section.

\section{***Insert Figure 1 about here***}

The primary data was collected from the entrepreneurs through semi-structured interviews in order to gain access to information on respondents' experiences and opinions (Saunders, Lewis \& Thornhill, 2012). An interview guide (King \& Horrocks, 2010) was developed including general questions about the background and activities of the entrepreneurs, and specific questions to recall incidences when the strategy of resource bricolage was adopted. As bricolage may be too abstract a concept for interviewees to understand, we broke down our questions into parts, using more accessible language. Although not all activities constituted bricolage, we considered it a good way to gain rapport and direct their focus towards activities that they had undertaken and on the ways resources had been utilised. Further questions were asked regarding the nature of these activities. For the research question concerning the nature of resources deployed by displaced entrepreneurs, the interviewers asked the entrepreneurs 
specifically about the different types of resources that they utilised in order to make these ventures happen (Table 2). The interviewers also recorded the outcomes of each of the business endeavours, in order to answer the question about how the implementation of bricolage affected business outcomes. For the research question concerning the utilisation of bricolage, the interviewers re-read the transcripts on returning from the fieldwork to confirm whether the activities mentioned fulfilled all the criteria of bricolage as stipulated by Baker and Nelson (2005). After analysing the data from the first interview, in some cases, further rounds of interviews were arranged to collect more information and clarify matters. Interviews lasted between 30 and 90 minutes, and most were digitally recorded and then transcribed. Some background information in relation to each of the entrepreneurs can be found in Table 3.

\section{***Insert Tables 2 and 3 about here***}

\section{Data Analysis}

The analysis was conducted first within each case and then cross-case comparison was carried out. The heterogeneity of the entrepreneurial process experienced by different individuals (Shane 1999; 2000; Baron, 2006; Baron and Ensley, 2006) implies that bricolage can only be understood if we have a clear view of the antecedents, in terms of the skills, knowledge, competencies, resources and networks developed, personally and as part of the business, behind each of the projects (Kwong, Tasavori and Cheung, 2017). Therefore, as a first step, we use the projects that the entrepreneurs became involved in to create a case history for analysis (Makkonen, Aarikka-Stenroos, and Olkkonen 2012, Pettigrew 1997, Polkinghorne 1995; Poole et al., 2000; Hedaa and Törnroos 2008). This approach allows us to examine how each of the projects was developed, in terms of whether bricolage had been deployed and the different resources utilised. In all cases, the entrepreneurs continued to develop their businesses and embarked on a number of different projects. We extracted from each entrepreneur between 2 
and 4 projects in total, giving us a total of 17 projects. The list of key projects is displayed in Appendix 1. It is important to note that, consistent with Berends et al (2014), the projects recorded do not represent the full range of activities which the enterprise has involved but, rather, those that the interviewees have personal experience of, and first-hand information about.

Second, following the approaches of Strauss and Corbin (1998) and Saldana (2015), we applied multiple coding schemes to identify five relevant issues based on our conceptual framework (Table 4). Third, we examined these projects comparatively, to compare and to generalise the analysis beyond each project (Ayres et al., 2003). Consistent with LeCompte and Schensul (1999), we examined the relation between these resources, personal attributes and attitudes, or any combination of them, and certain actions and behavioural outcomes. This enabled us, consistent with Merrill and West (2009), to identify common connections between themes across cases for theory generation. We then re-examined each of the individual narratives associated with each of the projects identified, and further explored whether personal and external contextualities may have a role to play in the adoption and deployment of that particular strategy or resource. We also noted down major abnormalities in terms of strategies deployed and resources utilised, and compare individual narratives to explore how these abnormalities could be attributed to the specific contextualities that each of them faced (Denzin and Lincoln, 2000). As we documented patterns in the data and constructed tentative theoretical explanations, we continued to use our data to challenge and extend our theory (Strauss and Corbin, 1998). During the repeated process of interrogating the data, revising the theory, and returning to the data, the themes we report in this paper eventually emerged. The eventual data structure is presented in Table 4. In our presentation of the results, we make use of a combination of illustrative examples and tables describing the data from which we drew our 
inferences (Miles and Huberman, 1994). When we introduce examples, we identified each of the entrepreneurs and indexed by the specific project identified.

$$
\text { *** Insert Table } 4 \text { about here } * * *
$$

\section{Results}

\section{Challenges in establishing their ventures post-displacement}

Two main themes came through as the obstacles to their entrepreneurship (re)engagement: first, the lack of pre-existing physical resources, and second, the lack of local knowledge to support such endeavours. In relation to the former, the sudden nature of war and conflict deprived them of the ability to gather resources prior to their departure. With Interviewee 4, he left all his carpentry tools back home as he was expecting a quick return:

Because the Army said that we will come back just in three days... all the tools which we were using were left in (home town)... I lost a lot during this passage of time, because my machinery now will not be in good condition. My tools would be rusty and not capable to work with. Since I left and I heard that a lot of the shops were cleared by the army... If I knew, I would have secured all my tools and equipment.

In many cases, the physical investments that they possessed for previous ventures, such as properties and machines, were relatively immobile, and in the contexts of war and conflict, cannot be easily sold (Interviewees 1, 2, 3, 4). In some other cases, these resources were repossessed, confiscated or even stolen (Interviewees 1, 3, 4). Interviewee 1, for instance, recalled:

We have properties, some shops and markets, in (my home town) and (a neighbouring town). We had a middle man who used to send us the rent but he told us that (the terrorists) have taken it. They threatened us, and said: "Give us the rent otherwise we 
do a blast and all will come down". So we said just give them so that they don't destroy the construction. We do not have other source of income. The properties get us the rent and what we eat and that was being taken by (the terrorists). You know, we have gone through a lot of pain you cannot imagine.

Similarly, in Interviewee 5's case, his business became untenable as his goods were repeatedly stolen or lost during transportation.

In some cases such as Interviewee 2, his shop at home was repeatedly destroyed. He recalled:

First, (the terrorists) blew it up in a bomb blast in the market. I spent a huge amount of money to make it profitable again. Afterwards, it got burnt down for unknown reasons... the third time, it was destroyed in the Army operation. I used to earn (a comfortable living) before the operation...now I have nothing left.

The limited resources that they have, however, will still need to be divided between household necessity and for the business, as discussed by Interviewee 3:

In the beginning, we faced problems regarding finance and location... I had to find a suitable and affordable place for the business, because we spent most of our capital on our new house which I now consider a mistake... We need a miracle with the little left from the construction of our home.

Whilst in normal circumstances locally available family finance would be a key source of finance for business start-up and growth in their cultural context (Pistrui et al., 2001), displaced individuals tend not to have such a strong family support system in place in the host country. According to Interviewee 4, for instance:

Not many people could support us in any way in starting our business... Our uncle helped us in some ways, and both our families lived together to support each other 
through the hardship... I guess he could have supported us, but he did not have much money, because he already has a large family to take care of. My uncle was dealing with a clothing business which was at its peak at the time, (but with the conflict) my uncle also suffered like us, a lot of money went in credit with the people to whom he gave clothes... I personally approached many relatives and close friends from school and college times, but all the efforts were in vain.

The second challenge highlighted was the lack of understanding of the local context. Interviewee 1 recalls:

We did not know anybody. We had no cousins, relatives here. So we were worried... We did not know the paths.

First, there is, amongst the displaced entrepreneurs, a lack of understanding of the local market preferences of the customers and this made life very difficult for a number of the entrepreneurs. For example, for Interviewee 2, there is the fact that "the locals have much less awareness of what my type of shop can do, in terms of printing and composing", with most other computer shops only running as "internet cafés for fun and entertainment". Whilst this presents an excellent market gap, this requires him to educate and inform his potential customers which is difficult to achieve without strong local connections. Therefore, despite having a monopoly in this area, he was making significantly less than what he earned prior to displacement.

Another problem is the lack of understanding of the local rules, regulations and norms. In trying to obtain a property for business, Interviewee 1 struggled even with the basic questions of: "What kind of properties are there? What is the commission? What is the rate?" In addition, lack of locational knowledge could cause significant economic losses, as stated by Interviewee 2 below: 
The first problem was to find an empty shop, which was very difficult, because I was not aware of the locations. It was a new place and new people... Due to problems I changed three shops.... It was very difficult to change shops and the stuff cannot be shifted in one day. It caused me some financial loss.

The finding is largely consistent with the findings of Cheung and Kwong (2017), who highlighted the difficulties in mobilising resources for venture start-up, as well as with both McKeever, Jack and Anderson (2015), and Cheung and Kwong (2017), the importance of local knowledge and resources. However, in the case of displaced individuals, both present major challenges in the starting up of businesses in the host location.

\section{Bricolage and the development of ventures}

Nevertheless, what is clear from the cross-case analysis of the narratives was Baker and Nelson's (2005) notion of 'refusal to enact limitations', whereby entrepreneurs refuse to accept the shortcomings that include those mentioned above, by engaging in various forms of bricolage. Consistent with other studies such as Di Domenico, Haugh and Tracey (2010), such refusal to enact 'limitations' is through the processes of 'making-do' and the 'reconfiguration of pre-existing resources and competencies'. In relation to making-do, it is noted that whilst entrepreneurs may have a strong desire to return to their sector of involvement, limited resources, local networks and knowledge means that pursuing a business of equivalent scale and scope to their pre-displacement venture(s) was often impossible. Entrepreneurs had to improvise and to accept making-do with less-than-ideal replacements as an inevitable part of the rehabilitation process, as found by Cheung and Kwong (2017). A notable downsizing in scale was apparent in all the ventures. In addition, with the context change as well as the loss of previous resources, a clear reconfigurations of business ideas and scopes was also noted across cases. The entrepreneurs often engaged in businesses that were related to their previous 
venture, but developed them based on both local conditions and resources availability, just as McKeever, Jack and Anderson (2015) and Cheung and Kwong (2017) suggested. Interviewee 1 moved from properties rental business to the running of a small hostel, where a demand grew from an emerging displaced student population, whose parents sent them to receive education in the host location because public schooling ceased to exist in the conflict zone. Interviewee 2 augmented his prior specialisations of computing programs and a specialist language software which enabled him to do advanced art work and compose advertisements, newsletters, etc., to now focusing on printing professional student IDs where there is a demand in the host location. Interviewee 3 followed the family's footsteps into the marble business, where he previously worked, and turned it into a wholesale operation buying processed marble from local factories and exporting it to a neighbouring country. Interviewee 4 became involved in a hybrid workshop whereby, with support from his car mechanic relative, he moved beyond the initial specialisation of carpentry by extending into metal repair work. Interviewee 5 moved from operating a business combining the selling of clothes and the commissioning of tailoredmade suits, to now operating a store selling a variety of clothing that was made by himself. Interviewee 6 moved from selling electronic appliances to the specialisation of solar panels and other solar-electricity-generated items. The outcomes of these activities enabled the displaced entrepreneurs to achieve their goal of re-engagement in business, despite possessing very few physical and financial resources.

Despite often remaining in the same sector, the displaced entrepreneurs tend to take on less prominent, more marginalised roles than they previously held. Interviewee 1 acknowledged that the role as a rental 'hostelier' is clearly much less prestigious than a landowner with a portfolio of properties. Interviewee 2 ended up with a thinner portfolio that is much narrower in scope, essentially placing all his eggs into the 'student ID printing' basket, potentially leaving him in a highly vulnerable position. Interviewee 6 shared a similar experience, moving 
into the specialisation of solar-electricity-generated items, because the local market for other electrical goods was already saturated. Interviewee 3 accepted that he would not be able to reestablish a marble factory immediately, and settled to a much more marginalised and less lucrative wholesale business within the supply chain. Interviewee 4 had to make-do with sharing a smaller workshop with his relative. He no longer focused on bespoke carpentry but adapted into doing all kinds of repair work involving wood and metal, the latter his relative's specialisation. He stated:

Whilst I have the ability to do any kind of work, I do not feel shame about doing any small jobs that usually people don't do. I would like to say as a good entrepreneur that one must do any type of work, especially the one in which they have experience and never feel a shame in small jobs. Because, taking risks and throwing shyness away is necessary for a business to develop.

Interviewee 5 had a similar experience of downsizing, and moving down from the specialisation of tailor-made suits to the selling of generic clothing based on local demands.

While the aims of these first bricolage activities often appear to fall short of those of their prior involvements, the displaced entrepreneurs used them as a platform to develop further business ideas. Some of those who have acquired adequate resources and competencies embark on the process of expansion, acquiring larger and better equipment for the same purpose (Interviewees $1,3,4)$. Others continued to apply bricolage and augmented their resources and competencies towards new purposes (Interviewees 1, 2,6). In one case, sensing the local demand which matched his career aspiration, the entrepreneur pursued the strategy of optimisation, breaking away from his previous sectors of involvement through deliberate planning and the acquisition of specific resources and competencies. The entrepreneur (Interviewee 5) left his brother in charge of his clothing stall, while he pursues a degree in order to set up a business in the 
pharmaceutical sector through externally acquired funding. In both the cases of bricolage and optimisation, these latest endeavours often only loosely resemble either what they did prior to displacement back home, or their initial ventures post displacement.

Alongside those moving from one businesses to another, others, such as Interviewees 2 and 3, operated in multiple endeavours concurrently, utilising mostly pre-existing resources and technical competencies. While running his printing business, he also devoted part of the floor space for mobile phone music downloads that required a similar infrastructure. In addition, with established contacts with headteachers from previous dealings, together with an established in-house apprenticeship, he made plans to set up a computer academy for school children. These augmentations are the results of having a clearer idea of the local demand within the host location. Owing to popular demand, Interviewee 6 extended his service to the assembling and repairing of solar and electrical goods. Interviewee 3 initially extended from marble wholesale to the establishment of a marble processing factory where their knowledge of the marble industry and the existing supply chain served as the crucial enabler for them to engage both in manufacturing and wholesaling. Once they became successful with manufacturing, they began to expand considerably, employing more people, operating in larger factories, and replacing rental, smaller machines with the purchase of larger ones that enabled them to resize marble as well as make cuttings on bigger stones. He later extended into international retail by establishing export outlets in a neighbouring country, in doing so reducing their reliance on the export houses that they had been dealing with. Interviewee 4 embarked upon an extending action in order to return to the status quo. He broke off the successful collaboration with his relative to each augment their resources and competencies to return to their respective previous professions.

Cross-case analysis reveals that these bricolage activities involved both internal and external resources of various domains, the key points of which are summarised below. 


\section{Internal resource mobilisation strategy under bricolage}

a) Utilisation of pre-existing human capital

With physical capital being in short supply for those affected by displacement, human capital becomes one of the few resources that remains available. Many of the projects developed by the entrepreneurs relied extensively on their pre-existing skills, knowledge and competencies. For instance, the computer skills that served Interviewee 2 well in his previous designing and composing business became very relevant to his subsequent ID printing and mobile music download projects. Similar utilisation of human capital can be found in every other case, including Interviewee 1's experience in the property rental business, Interviewee 3's experience in the marble industry, Interviewee 5's tailoring skills, and Interviewee 6's knowledge of whitegoods and electrical appliances. The extensive utilisation of pre-existing human capital has a strong effect on the direction of bricolage, as it confined displaced entrepreneurs into internal bricolage that reinforced their pre-displacement business path.

Over time, our finding suggests that further bricolage attempts continued to rely heavily on pre-established human capital, but what is important to note is that the human capital of the entrepreneurs continued to develop post-displacement, and most particularly, the development of vital local and locational knowledge that they did not have in the first place. These include location information for the best premise (Interviewee 1, 2, 3, 4), local knowledge such as market demands (such as Interviewee 2's mobile music download project, Interviewee 6's electrical repairing project) and awareness of crucial players within the local sector (Interviewee 4's new connections with different players within the supply chain, and Interviewee 2's contacts with headteachers). By this point they have also become increasingly familiar with the local rules and customs, which means that they no longer required the help of contacts and others as they did when they entered into their first venture. 


\section{External resource mobilisation strategy under bricolage}

It was also apparent that external resources were deployed for each of the bricolage attempts, with some of the key ones highlighted below.

a) Utilisation of a frugal approach towards resources acquisitions

With limited physical resources, most of the interviewees applied frugal resources in their initial bricolage attempts to minimise costs. Interviewee 3, for instance, discusses the need to 'do a miracle' with the little resources that they have, and initially bought second hand machines for the venture. Similarly, Interviewee 4 bought 'old and used hand tools' that were 'stressful' to use, since he could not afford new tools. With severe financial constraints, they were also frugal in keeping their expenses to the absolute minimum that could still fulfil their business needs. Interviewee 3 stated: 'No, we don't have such kind of resources to do things that do not benefit us directly'. Interviewee 4 started with 'just a few tools', whilst for the printing business, Interviewee 2 only bought 'one computer, one printer, one scanner and table'. For Interviewee 5, his clothing business required nothing more than a sewing machine, which he pre-owned, and a stall in the market.

Similarly, all opted for smaller premises compared to the optimal size that they envisaged. Considerable time is devoted in the searching process to ensure their cost effectiveness. Interviewee 3, for instance, recalls that he had to 'walk for four to five hours a day around the host town and the computing markets to find a suitable and affordable place' for his premise.

Family members provide a low cost and even free workforce on an ad-hoc basis, such as the family members living in the hostel run by Interviewee 1, and the family of interviewee 5 who learnt from him the skill of sewing and mending. Despite being involved in a relatively technical sector of computing, Interviewee 2 deployed an in-house training strategy which enabled him to fill his workforce with low cost labour. He explains: 
I have trained some illiterate and uneducated pupils and now they can do any sort of work in my shop. My apprentice, who has been with me for the last two years, is an uneducated boy, but can do all the documentation work properly. He can do all sorts of work in my shop and also handles the shop in my absence.

Frugality is also applied to the operation process. Interviewee 5 did away with the complicated double-charging of commissions from clothing-maker and customers, because such an operational model would not work in a new context. Instead, he now bought clothes from various suppliers, and charged the customers directly for the end-products.

\section{b) Multiple applications of resources}

Another approach to minimise resource usage is through the multiple applications of resources whereby previously these were only used for a single purpose. For instance, Interviewee 1 used the business premise, a rented hostel, for dual business and residential purposes, which spared them the cost of having to make two investments. Similarly, Interviewee 4 collaborated with his relative to expand his business scope into a hybrid carpentry/woodwork workshop, which enabled both to share the same rental premises and some of the common tools to save costs, while coming under the same banner of craftwork and repair. The multiple application principle is also applied to the labour force, as well as the premises. While Interviewee 6 ran the business of solar electrical equipment in his premises, he himself also doubled up as an electrician for the assembling, installation and repair of electrical items.

\section{A clandestine network approach towards resource mobilisation}

Throughout the narrative, what came out very strongly is the utilisation of clandestine networks in the acquisitions of resources, competencies and knowledge. In this section, we highlight some of the key roles that clandestine networks played in their mobilisations. 
a) Supply chain and customer network

Clandestine networks that were established prior to displacement appear crucial in providing vital links within the supply chain. Interviewee 4, for instance, continued to import wood from the conflict-affected regions near his home town, where the wood was renowned to be of good quality. Similarly, Interviewee 6 continued to bring in his stock from Peshawar, a nearby city, while Interviewee 3 continued to export to a neighbouring country through their pre-established network of export houses for their marble business. These networks allowed them to bypass the difficulties in breaking into the local supplier's network.

Clandestine networks were also an important source of customers for some. Interviewee 1's hostelling business would not exist without the students who fled his home region. Similarly, Interviewees 4, 5 and 6 relied heavily on customers who came from their home regions, particularly those who already visited them in their home towns prior to displacement. Reputation that disseminates through word-of-mouth is particularly crucial for this kind of business.

b) Gateway to local knowledge

Whilst lack of local knowledge is an issue for displaced entrepreneurs, a few were fortunate to be able to draw on their networks which were based in the host location for help. For Interviewee 1, a friend who came to the same city a few years prior to his displacement provided a lot of support in finding the right premises. For instance, Interviewee 1 stated that:

There was one person who used to study with me in (my home town). He migrated some time ago (3-4 years) and had bought a house. I told him that I needed a house and he guided me. He helped me in finding a house, and said to the man, "Give this property to him". He really helped me a lot because we didn’t know the rules and regulations. We got the house to rent. 
For Interviewee 2, his uncle, who was a landowner of a market in the host location, provided him with valuable information, not only in terms of choosing the venue, but also in offering other practical advice regarding rules, regulations, norms and customs.

\section{c) Labour networks}

With displaced entrepreneurs struggling to employ local workers due to language barriers, norms and other unknown elements that may affect their perceived reliability, many turned to clandestine labour networks as their source of labour (Bizri, 2017). Interviewee 2, for instance, contacted other migrants from his home town by phone and invited them to become his apprentices for his printing business. Others restricted their workers' pool to their family members. The relatives who stayed in the hostel in the case of Interviewee 1 could double up as ad-hoc labour when required. For Interviewee 5, the presence of family members who ran the stall for him enabled him to plan and move on to a potentially more lucrative business opportunity, without having to worry about losing the business to an apprentice from outside who may take all the businesses and start-up elsewhere.

\section{d) Finance and resource acquisition}

Amongst displaced entrepreneurs, financial bricolage appears crucial in the acquisition of external resources. With the exception of Interviewee 3 who relied solely on internal resources, many of the entrepreneurs at this stage utilised their pre-existing network for financial support. However, in contrast with Cheung and Kwong (2017) who noted a local network finance approach being deployed, our interviewees spoke of the inability of immediate family who are based locally to offer financial support, largely because they faced similar problems. Interviewee 1 elaborated on the challenge:

Everybody including us faced doomsday. No one could help even their sons or parents, because everyone was facing their own problems. 
Similarly, Interviewee 4 struggled to obtain finance from those who were based locally:

One of my brothers is (in a nearby town)... I called him for help, he could not provide any financial support, because he was in the business of oranges and he invested all the money he had.

Thus, deprived of channels by which to access local resources through either within the network or the host's enterprise ecosystem, our entrepreneurs went further afield. For most, these sources that they relied on continued to come from within their pre-established network. The main sources were from family and relatives who had migrated to other parts of the world. Interviewee 1 relied on multiple sources of finance, combined finance from a cousin and a relative in an Arab country, and a friend in a western country who gave him loans to start off the hostel business. Interviewee 2 drew from an uncle who is "very rich and owned a huge logistics business in (an Arab country) with 50-60 container carriers'. Interviewee 3 had requested his son, who he sent to an Arab country to work as a driver, to wire money back in supporting his joint venture with a relative. Most of their supporters were economic migrants who often chose to go to locations that presented them with the best business opportunities. In contrast, where the displaced population had ended up was not necessarily more prosperous than where they came from originally, and thereby the economic and population connections between the two tended not to be as strong. As an entrepreneur operating a venture with social elements, support for Interviewee 6 came from even further field. Some of her supporters came not only from those who were known to her personally, but also those who were from the same ethnicity - some were migrants while others had gone through the same displacement process themselves, sometimes a few decades ago and others more recently, and therefore identified strongly with the objectives of the social elements. 
In terms of the usage of finance, most were utilised to acquire physical investments, mostly properties (Interviewees 1, 2, 3, 4, 6), either as rental or purchase, but also small tools and equipment (Interviewees 2, 3, 4). These loans are often small scale, flexible, and informal in nature. When the loan is not from an immediate family member, creditability of the lender was assessed through one's personal standing within the clan. For instance, Interviewee 2 recalls:

My uncle did not have any problem in providing me money. He consoled me regarding this, because he was well aware of my character, career and business. He was my uncle like a father, so he could not deny my proposal and told me to carry on my business.

Whilst most were in the form of loans, sometimes finance was also acquired through other networks and in different manners. For instance, Interviewee 3 worked out an arrangement with the miners who had long been part of their network and were willing to provide them with raw materials on a credit basis.

\section{Discussions and conclusion}

\section{Theoretical implications}

Consistent with other studies examining entrepreneurship in penurious environments (Di Domenico, Haugh and Tracey, 2010; Rego et al., 2014; Linna, 2013), our findings suggest that bricolage plays a crucial role in enabling entrepreneurial individuals amongst a displaced population facing severe resource constraints to start up a business in the host location. As Turner (2010) suggested, marginalisation and poor access to physical resources within the host's enterprise ecosystem appear as a key hindrance in their start-up efforts. We found evidence of resource replacement (Ryan et al, 2008), and that the key part of the resource mobilisation strategy of all entrepreneurs was to 'make-do' with the restricted sets of resource endowments, through utilising a repertoire of internal skills, knowledge and competencies that they developed through their life's course to compensate for their lack of physical resource 
availability. New ventures were created, as Nelson and Baker (2005) suggested, through reconfiguring these competencies, combined with a highly-restrained approach towards the acquisition and uses of additional resources, and using these resources in ways that were novel and largely unexpected to create new business ideas and ventures. We found that, when additional resources had been obtained, a frugal approach emphasising on-cost minimisation had been evident. In addition, we also found that many entrepreneurs utilised the same resources for multiple functions in order to maximise their utility. These findings are consistent with existing studies such as Wauters and Lambrecht $(2006,2008)$.

Our contribution lies with our identification of the specific forms of network that facilitate the resource mobilisation process for entrepreneurs adopting the strategy of bricolage. Consistent with Baker, Miner and Eesley (2003), we also found network bricolage to be crucial in the acquisition of different domains of resources. However, whilst Cheung and Kwong (2017) asserted the crucial role of pre-established local networks in the development of entrepreneurial endeavours in the wartime situation, or in Kwong et al (2017) where social enterprises relied heavily on establishing new network partnerships with other social organisations, we found that for displaced entrepreneurs there is a liability of foreignness, with their limited preestablished connections within the host location considerably affecting their ability to acquire the necessary local resources and knowhow for start-up. Consistent with Turner (2010), displaced entrepreneurs tended to have few pre-established local connections within host population, with the people that they knew in the host location tending to be those who were themselves displaced and thereby unable to offer support. Nevertheless, the displaced entrepreneurs in our study came up with a number of strategies involving their clandestine network in support of their bricolage endeavours. For a fortunate few, they were able to draw from those within their clan who arrived in the host location prior to the conflict, and had accumulated sufficient resources and knowledge so that they were in the position to support 
others within their clandestine network who were in need. These supports include both financial resources as well as the supply of local information and knowledge. Nevertheless, these resources alone tend not to be sufficient and most do not have the luxury of drawing from such connections. Facing a new market with little certainty of the conditions of local demand, many, as Steele (2009) suggested, sourced their customers from their clandestine enclaves to compensate for their lack of connection with the host population. Similarly the use of a clandestine workforce, many of whom were underemployed in the host location due to integration difficulties, offered a 'win-win' situation for both parties and eliminated the need to reach out to the local workforce that could be culturally and linguistically different.

Alongside those who are available locally as mentioned above, we also found evidence that the displaced entrepreneurs drew from clandestine networks from further afield. The reengagement with the pre-established supply chain that they developed prior to conflict, even for a different line of business, eliminated the need for the displaced entrepreneurs to be fully embedded within the host ecosystem, but rather, helped create a parallel system whereby their operation is only loosely connected with the host ecosystem at large, and thereby reduces dependency on it. Consistent with Ratha and Mohapatra (2007), clandestine networks from further afield also serve as an important source of finance. A number of displaced entrepreneurs drew heavily from their clandestine network that were neither based in the home, nor the host locations, but from those who migrated to a 'safe' third country unaffected by conflict (Ratha, 2007). Once again, such an approach enabled them to bypass the established financial institutions in the host location, which often looked unfavourably on their applications due to their displacement status.

Our study is also consistent with previous studies such as Nelson and Baker (2005) and Senyard et al. (2015), in that the use of internal bricolage did result in the development of smaller ventures with low growth potential. Consistent with the conservation of resources theory 
(Hobfoll, 2001), we found that the initial underlying motive of these early ventures is to return to the status quo prior to displacement. However, as time went on, we noted what Habbershon (2006) considered as resource substitution, and, consistent with Portes and Sensenbrenner (1993), resources within the host ecosystem were being utilised. Some displaced entrepreneurs were able to break away from parallel bricolage, extending into new business directions not initially envisaged. This is largely through the utilisation of the additional resources and knowledge and local knowhow that they have acquired over time. This suggests that, unlike in previous studies such as Fisher (2012) suggesting that bricolage could confine displaced entrepreneurs to a vicious circle with little scope to transform, they could, over time, break away from it.

\section{Policy and managerial implications}

The study demonstrates the key role of clandestine pre-established networks in the development of entrepreneurial activities amongst displaced entrepreneurs. Governments should support those affected by displacement by helping to establish bottom-up, local selfhelp forms of support, with the aim of facilitating local knowledge, resource and network dissemination in aid of business start-ups. This would enable them to survive through such difficult periods.

However, there comes the questions of integration and transition. While clandestine networks can be useful, our results show that they often limited the potential of these ventures to being subsistence based. It would then take considerable time before they could upscale, connecting both with the local market demands and the host enterprise ecosystem, and become profitable. Therefore, governments should help in making the transition quicker and smoother, which would not only help economically, but psychologically. We offer some recommendations. First, governments could provide elementary training on the host ecosystem, covering political, 
financial and legal aspects. Second, they could offer field trips and other market support to improve local knowledge. Finally, they could also provide networking events with the locals, including entrepreneurs, investors and suppliers, through apprenticeship, mentoring and business lunches, to bridge the knowledge and competencies gap. Some of these programmes have been implemented in the western world but they should be implemented more widely (Harima and Freiling, 2016). For these programmes to succeed, it would also be crucial for the government to mobilise public support. There is often a stigma attached to the displaced population, as a drain on local resources (Strang and Ager, 2010). Awareness programmes could help the locals understand the benefits of a well-integrated displaced population that would result in harmony and could be mutually beneficial (Klocker and Dunn, 2003).

In our case where the government has limited capacity to support the entrepreneurs, international development organisations could step into the institutional void (Mair and Marti, 2009). Traditionally focused on relief work in the context of displacement (Duffield, 1997), it is important for them to recognise the power of entrepreneurship, both in terms of sustainability but also for empowerment, and bring entrepreneurship to the forefront of displacement work (Helmsing, 2015). The United Nations Development Programme, for instance, has developed enterprise training within their transition and recovery programme in Pakistan for the displaced population, focusing on financial literacy, business planning and other technical elements (UNDP, 2017). Nevertheless, few of the studies focused on the 'softer' skills, most notably those mentioned above, that would be just as crucial.

From a psychological point of view, being displaced with little certainty about what the future holds is a traumatic experience. Resilience can play an important part in enabling entrepreneurs to overcome crisis situation (Williams and Volery, 2017). It is important that the entrepreneur can recognise bricolage as a legitimate business strategy in helping them to fully utilise the meagre resources that they have in their possession, and reconfigure them in innovative ways 
to capture opportunities within the existing market that no one else has noticed. They should also continue to explore ways to efficiently utilise their pre-established clandestine networks, whether they are located in the home or host country or a third location away from conflict, to offer them an alternative competitive advantage. They also need to be aware of the support that is on offer. Finally, once they have gained a foothold, it would be important for them to consider a strategy beyond bricolage, but towards optimisation.

\section{Limitations}

Finally, we would like to discuss the limitations of the study and recommendations for further research. Firstly, a quantitative study involving an enriched sample size would enable a confirmatory approach in examining the relationship between bricolage, resource utilisation strategies, and performance outcomes. Secondly, the roles of economic, cultural and linguistic differences could be further elaborated in future studies as these could affect the ability of displaced entrepreneurs to integrate into the host location. Thirdly, our study could be extended to examine other forms of displacement, including refugees, asylum seekers and stateless persons. Fourthly, future studies could examine displaced entrepreneurs who lived within camps rather than in the population at large, whose ventures are likely to have very different characteristics. Finally, studies could examine the path development of these entrepreneurial ventures. Nevertheless, whilst resource constraints for displaced individuals often confine entrepreneurial individuals to embark upon bricolage in order to repair, once they have gained a foothold in the market they are no longer being confined to bricolage. As they begin to accumulate physical resources and local knowhow, an approach focusing on optimisation rather than bricolage (Basu and Desa, 2012) may be more relevant. However, further analysis of their longitudinal path development is beyond the remit of this paper and therefore further study towards this would be welcomed. 


\section{References}

Abu-Lughod, L., 2002. Do Muslim women really need saving? Anthropological reflections on cultural relativism and its others. American anthropologist, 104(3), pp.783-790.

Ayres, L., Kavanaugh, K., Knafl, K. (2003) Within-case and across-case approaches to qualitative data analysis. Qualitative Health Research, 13, 6, 871-883

Assaf, G. and El-Fil, R., 2000. Resolving the issue of war displacement in Lebanon. Forced Migration Review, 7, pp.31-3.

Baker, Ted, Anne S. Miner, and Dale T. Eesley. 2003. "Improvising firms: bricolage, account giving and improvisational competencies in the founding process." Research Policy 32 (2):255-276.

Baker, Ted, and Reed E. Nelson. 2005. "Creating Something from Nothing: Resource Construction through Entrepreneurial Bricolage." Administrative Science Quarterly 50 (3):329-366.

Baron, R.A., 2006. Opportunity recognition as pattern recognition: How entrepreneurs "connect the dots" to identify new business opportunities. The Academy of Management Perspectives, 20(1), pp.104-119.

Baron, R.A. and Ensley, M.D., 2006. Opportunity recognition as the detection of meaningful patterns: Evidence from comparisons of novice and experienced entrepreneurs. Management science, 52(9), pp.1331-1344.

Benight, C.C., Ironson, G., Klebe, K., Carver, C.S., Wynings, C., Burnett, K., Greenwood, D., Baum, A. and Schneiderman, N., 1999. Conservation of resources and coping selfefficacy predicting distress following a natural disaster: A causal model analysis where the environment meets the mind. Anxiety, stress and coping, 12(2), pp.107-126.

Bizri, R.M., 2017. Refugee-entrepreneurship: a social capital perspective. Entrepreneurship \& Regional Development. Online first DOI: perspective: 10.1080/08985626.2017.1364787

Bullough, A., Renko, M. and Myatt, T., 2014. Danger zone entrepreneurs: The importance of resilience and self-efficacy for entrepreneurial intentions. Entrepreneurship Theory and Practice, 38(3), pp.473-499.

Cheung, C. and Kwong, C (2017) Path-and Place-dependence of entrepreneurial ventures at times of war and conflict. International Small Business Journal. Published online

Dacin, P.A., Dacin, M.T. and Matear, M., 2010. Social entrepreneurship: Why we don't need a new theory and how we move forward from here. The academy of management perspectives, 24(3), pp.37-57.

Desa, Geoffrey, and Sandip Basu. 2013. "Optimization or Bricolage? Overcoming Resource Constraints in Global Social Entrepreneurship." Strategic Entrepreneurship Journal 7 (1):26-49.

de Bruin, A., Shaw, E. \& Lewis, K. (2017) The collaborative dynamic in social entrepreneurship, Entrepreneurship \& Regional Development, 29:7-8, 575-585, DOI: $10.1080 / 08985626.2017 .1328902$

Doern, R., Williams, N. and Vorley, T. (2016) Entrepreneurship and crises: business as usual? Entrepreneurship \& Regional Development, 28 (5-6), 471-475.

Doern, R. (2016). Entrepreneurship and Crisis Management: The Experiences of Small Businesses during the London 2011 Riots. International Small Business Journal 34 (3): 276-302

Doern, R. (2017). Strategies for resilience in entrepreneurship: Building resources for small business survival after a crisis. In Vorley, T. and Williams, N (Eds.), Creating Resilient Economies: Entrepreneurship, Growth and Development in Uncertain Times, Edward Elgar. 
Duffield, M., 1997. NGO relief in war zones: towards an analysis of the new aid paradigm. Third World Quarterly, 18(3), pp.527-542.

Duvander, A.Z.E., 2001. Do country-specific skills lead to improved labor market positions? An analysis of unemployment and labor market returns to education among immigrants in Sweden. Work and Occupations, 28(2), pp.210-233.

Eisenhardt, K.M. and Graebner, M.E., 2007. Theory building from cases: Opportunities and challenges. Academy of management journal, 50(1), pp.25-32.

Ellis, S. and Barakat, S., 1996. From Relief to Development: The Long-term Effects of 'Temporary'Accommodation on Refugees and Displaced Persons in the Republic of Croatia. Disasters, 20(2), pp.111-124.

Fisher, G., 2012. Effectuation, causation, and bricolage: a behavioral comparison of emerging theories in entrepreneurship research. Entrepreneurship theory and practice, 36(5), pp.1019-1051.

Garud, Raghu, and Peter Karnøe. 2003. "Bricolage versus breakthrough: Distributed and embedded agency in technology entrepreneurship." Research Policy 32 (2):277-300.

Gibbert, M. and Scranton, P., 2009. Constraints as sources of radical innovation? Insights from jet propulsion development. Management \& Organizational History, 4(4), pp.385-399.

Goodhand, J., 2000. Research in conflict zones: ethics and accountability. Forced Migration Review, 8(4), pp.12-16.

Graebner, M.E., Martin, J.A. and Roundy, P.T., 2012. Qualitative data: Cooking without a recipe. Strategic Organization, 10(3), pp.276-284.

Halme, M., Lindeman, S. and Linna, P., 2012. Innovation for inclusive business: Intrapreneurial bricolage in multinational corporations. Journal of Management Studies, 49(4), pp.743-784.

Halbesleben, J.R. and Bowler, W.M., 2007. Emotional exhaustion and job performance: the mediating role of motivation. Journal of applied psychology, 92(1), p.93.

Harima, A., \& Freiling, J., Workshop on Refugee Entrepreneurship, ICSB2016, 15.-18. Juni, 2016, New York/New Jersey (USA)

Hedaa, L. and Törnroos, J.Å., 2008. Understanding event-based business networks. Time \& Society, 17(2-3), pp.319-348.

Hewerdine, J., Rumyantseva, M. and Welch, C. 2014. "Resource scavenging: Another dimension of the internationalisation pattern of high-tech SMEs." International Marketing Review 31, no. 3: 237-258.

Habbershon, T.G., 2006. Commentary: A framework for managing the familiness and agency advantages in family firms. Entrepreneurship theory and practice, 30(6), pp.879-886.

Helmsing, A.B., 2015. Conditions for social entrepreneurship. International Journal of Social Quality, 5(1), pp.51-66.)

Hobfoll, S.E., 2001. The influence of culture, community, and the nested-self in the stress process: advancing conservation of resources theory. Applied Psychology, 50(3), pp.337421.

Huybrechts, B., Nicholls, A. \& Edinger, K. (2017) Sacredalliance or pact with the devil? How and why social enterprises collaborate with mainstreambusinesses in the fair trade sector, Entrepreneurship \& Regional Development, 29:7-8, 586-608

Jayawarna, D., Jones, O. and Macpherson, A., 2014. Entrepreneurial potential: The role of human and cultural capitals. International Small Business Journal, 32(8), pp.918-943.

Kariv, D. and Coleman, S., 2015. Toward a theory of financial bricolage: the impact of small loans on new businesses. Journal of Small Business and Enterprise Development, 22(2), pp.196-224.

King, N. and Horrocks, C., 2010. Interviews in qualitative research. Sage. 
Klocker, N. and Dunn, K.M., 2003. Who's driving the asylum debate? Newspaper and government representations of asylum seekers. Media International Australia Incorporating Culture and Policy, 109(1), pp.71-92.

Krahn, H., Derwing, T., Mulder, M. and Wilkinson, L., 2000. Educated and underemployed: Refugee integration into the Canadian labour market. Journal of International Migration and Integration, 1(1), pp.59-84.

Kwong, C., Tasavori, M. and Cheung, C. (2017) Bricolage, Collaboration and Mission Drift in Social Enterprises. Entrepreneurship and Regional Development

Lai, Y., G. Saridakis, R. Blackburn, and S. Johnstone. 2016. Are the HR Responses of Small Firms Different from Large Firms in times of Recession? Journal of Business Venturing 31 (1): 113-131.

LeCompte, M. D., \& Schensul, J. J. (Eds.). (1999). Analyzing and interpreting ethnographic data. Rowman Altamira.

Lee, J.H. and Venkataraman, S., 2006. Aspirations, market offerings, and the pursuit of entrepreneurial opportunities. Journal of Business Venturing, 21(1), pp.107-123.

Levi-Strauss, Claude. 1967. The Savage Mind. Chicago: University of Chicago Press.

Lewis, K.V., 2013. The power of interaction rituals: The Student Volunteer Army and the Christchurch earthquakes. International small business journal, 31(7), pp.811-831.

Lincoln, Y.S. and Denzin, N.K., 2000. The seventh moment: Out of the past. Handbook of qualitative research, 2, pp.1047-1065.

Linna, P., 2013. Bricolage as a means of innovating in a resource-scarce environment: A study of innovator-entrepreneurs at the BOP. Journal of Developmental Entrepreneurship, 18(3), p.135-155

Mac Sweeney, N., 2008. Private-Sector Development in Post-Conflict Countries. The Donor Committee of Enterprise Development, International Labour Organisation, Turin.

Mair, J. and Marti, I., 2009. Entrepreneurship in and around institutional voids: A case study from Bangladesh. Journal of business venturing, 24(5), pp.419-435.

Makkonen, H., Aarikka-Stenroos, L. and Olkkonen, R., 2012. Narrative approach in business network process research-Implications for theory and methodology. Industrial Marketing Management, 41(2), pp.287-299.

Marvin G. Weinbaum (2017) Insurgency and Violent Extremism in Pakistan, Small Wars \& Insurgencies, 28:1, 34-56.

McKeever, E., Jack, S. and Anderson, A. (2015) Embedded entrepreneurship in the creative re-construction. Journal of Business Venturing, 30, 50-65.

Merrill, B., \& West, L. (2009). Using biographical methods in social research. Sage. Milliken, F. J. 1987. Three types of perceived uncertainty about the environment: State, effect, and response uncertainty. Academy of Management Review, 12, 133-143.

Miles, M.B. and Huberman, A.M., 1994. Qualitative data analysis: A sourcebook. Beverly Hills: Sage Publications.

Pistrui, D., Huang, W., Oksoy, D., Jing, Z. and Welsch, H., 2001. Entrepreneurship in China: Characteristics, attributes, and family forces shaping the emerging private sector. Family Business Review, 14(2), pp.141-152.

Polkinghorne, D.E., 1995. Narrative configuration in qualitative analysis. International journal of qualitative studies in education, 8(1), pp.5-23.

Pettigrew, A.M., 1997. What is a processual analysis?. Scandinavian journal of management, 13(4), pp.337-348.

Portes, A. and Sensenbrenner, J., 1993. Embeddedness and immigration: Notes on the social determinants of economic action. American journal of sociology, 98(6), pp.1320-1350.

Preece, S.B., 2014. Social bricolage in arts entrepreneurship: building a Jazz society from Scratch. Artivate: A Journal of Entrepreneurship in the Arts, 3(1), pp23-34. 
Ratha, D., 2007. Leveraging remittances for development. Policy Brief, 3.

Ratha, D. and Mohapatra, S., 2007. Increasing the macroeconomic impact of remittances on development. World Bank.

Rego, A., Oliveira, P., Rosado, P. and Habib, N., 2014. Product Innovation in Resource-Poor Environments: Three Research Streams. Journal of Product Innovation Management, 31(2), pp.202-210.

Saldaña, J. (2013). The coding manual for qualitative researchers (No. 14). Sage.

Saunders, M.L. and Lewis, P., 2009. P. \& Thornhill, A.(2009). Research methods for business students, 4.

Sinclair, M., 2001. Education in emergencies. Learning for a future: Refugee education in developing countries, in Secretariat, C., 2006. Commonwealth Education Partnerships. Commonwealth Secretariat. pp.52-56.

Stinchfield, B.T., Nelson, R.E. and Wood, M.S., 2013. Learning from Levi-Strauss' legacy: art, craft, engineering, bricolage, and brokerage in entrepreneurship. Entrepreneurship theory and practice, 37(4), pp.889-921.

Senyard, J., Baker, T., Steffens, P. and Davidsson, P., 2014. Bricolage as a path to innovativeness for resource-constrained new firms. Journal of Product Innovation Management, 31(2), pp.211-230.

Shane, S., 2000. Prior knowledge and the discovery of entrepreneurial opportunities. Organization science, 11(4), pp.448-469.

Steele, A., 2009. Seeking safety: Avoiding displacement and choosing destinations in civil wars. Journal of Peace Research, 46(3), pp.419-429.

Stiglitz, J.E. and Weiss, A., 1981. Credit rationing in markets with imperfect information. The American economic review, 71(3), pp.393-410.

Stinchfield, Bryan T., Reed E. Nelson, and Matthew S. Wood. 2013. "Learning From LeviStrauss' Legacy: Art, Craft, Engineering, Bricolage, and Brokerage in Entrepreneurship." Entrepreneurship: Theory \& Practice 37 (4):889-921. doi: 10.1111/j.15406520.2012.00523.x.

Strang, A. and Ager, A., 2010. Refugee integration: Emerging trends and remaining agendas. Journal of Refugee Studies, 23(4), pp.589-607.

Strauss, A., \& Corbin, J. (1998). Basics of qualitative research: Procedures and techniques for developing grounded theory. ed: Thousand Oaks, CA: Sage.

Stritar, R., 2012. RESOURCE HIJACKING AS A BRICOLAGE TECHNIQUE. Economic \& Business Review, 14(1).

Tasavori, M., Kwong, C. and Pruthi, S. (forthcoming) 'Resource Bricolage, and ProductMarket Scope of Social Enterprises', Entrepreneurship and Regional Development.

Tracey, P. and Phillips, N., 2007. The distinctive challenge of educating social entrepreneurs: A postscript and rejoinder to the special issue on entrepreneurship education. Academy of Management Learning \& Education, 6(2), pp.264-271.

Turner, T., 2010. The jobs immigrants do: issues of displacement and marginalisation in the Irish labour market. Work, Employment and Society, 24(2), pp.318-336.

UNDP (2017) Federally Administered Tribal Areas Transition and Recovery Programme. Accessed from: http://www.pk.undp.org/content/pakistan/en/home/operations/projects/crisis_prevention _and_recovery/early-recovery-assistance-framework-for-fata.html. Accessed on: 5 Oct 2017 .

UNHCR Fact Sheet (May, 2016) retrieved from http://reporting.unhcr.org/sites/default/files/UNHCR\%20Pakistan $\% 20$ Factsheet $\% 20$ \%20MAY16.pdf. Accessed on 5 oct 2017. 
UNHCR (2017) What is a refugee? Accessed from: http://www.unrefugees.org/what-is-arefugee/. Accessed on 5 Oct 2017.

Wauters, B. and Lambrecht, J., 2006. Refugee entrepreneurship in Belgium: Potential and practice. The International Entrepreneurship and Management Journal, 2(4), pp.509-525.

Wauters, B. and Lambrecht, J., 2008. Barriers to refugee entrepreneurship in Belgium: Towards an explanatory model. Journal of Ethnic and Migration Studies, 34(6), pp.895915. 
Weick, K.E., 1998. Introductory essay-Improvisation as a mindset for organizational analysis. Organization science, 9(5), pp.543-555.

Williams, N. and Vorley, T. (2017). The resilience of entrepreneurs and small crisis in the depths of a recessionary crisis, in N. William and T. Vorley (eds) Creating Resilient Economies: Entrepreneurship, Growth and Development in Uncertain Times. Edward Elgar Publishing.

Yin, R.K., 2012. Case study research: Design and methods. Sage publications. 
Table 1. Different forms of bricolage highlighted in the existing literature

\begin{tabular}{|c|c|c|c|}
\hline & Description & Perceived advantages & Perceived disadvantages \\
\hline $\begin{array}{l}\text { Internal/ } \\
\text { Parallel (Baker } \\
\text { and Nelson, } \\
\text { 2005) }\end{array}$ & $\begin{array}{l}\text { The employment of at-hand resources that } \\
\text { reside within an organisation. It often relies on } \\
\text { the utilisation of a diverse repertoire of } \\
\text { resources that were previously hoarded but } \\
\text { which had no immediate intention of being used. }\end{array}$ & $\begin{array}{l}\text { Cost minimalization: Entrepreneurs engaged in } \\
\text { internal bricolage often exhibit an impressive } \\
\text { ability to get by, or do without resources that } \\
\text { other ventures considered essential (Baker and } \\
\text { Nelson, 2005). }\end{array}$ & $\begin{array}{l}\text { Not the desired outcome by choice, but pragmatic } \\
\text { compromise based on resource availability. } \\
\text { Mutually reinforcing, interlocking behaviours and } \\
\text { expectations that are difficult to break out from. } \\
\text { May lose sight of the goals and objectives. }\end{array}$ \\
\hline $\begin{array}{l}\text { External/ } \\
\text { Selective }\end{array}$ & $\begin{array}{l}\text { A hybrid approach supplementing internal } \\
\text { bricolage by acquiring additional resources } \\
\text { strategically from elsewhere. }\end{array}$ & $\begin{array}{l}\text { Entrepreneurs preserve the ability to choose to } \\
\text { embark upon the products and services they } \\
\text { perceive will generate growth. }\end{array}$ & $\begin{array}{l}\text { Require additional resources which can be difficult } \\
\text { to obtain in a penurious context. }\end{array}$ \\
\hline $\begin{array}{l}\text { Network } \\
\text { (Baker et al., } \\
\text { 2003) }\end{array}$ & $\begin{array}{l}\text { Utilising resources residing within their pre- } \\
\text { existing personal and professional networks. }\end{array}$ & \multirow{3}{*}{$\begin{array}{l}\text { Networks enable entrepreneurs to access a } \\
\text { much broader variety of resources-at-hand, and } \\
\text { is especially relevant to entrepreneurs operating } \\
\text { within resource-poor, but particularly high- } \\
\text { context culture and communities (Dacin, Dacin, } \\
\text { and Matear 2010). }\end{array}$} & \multirow{3}{*}{$\begin{array}{l}\text { The type of bricolage created is dependent on the } \\
\text { particular form of partnership, or the dynamics } \\
\text { between the different departments within the } \\
\text { intrapreneurship partnership case, and the more } \\
\text { dominant the partner is, the less autonomy these } \\
\text { entrepreneurs enjoy in their bricolage efforts. }\end{array}$} \\
\hline $\begin{array}{l}\text { Collaborative } \\
\text { (Kwong et al., } \\
\text { 2017) }\end{array}$ & $\begin{array}{l}\text { Utilising various forms of business networks that } \\
\text { are often bound by more formal partnership } \\
\text { arrangements }\end{array}$ & & \\
\hline $\begin{array}{l}\text { Intrapreneurial } \\
\text { (Halme et al., } \\
\text { 2012). }\end{array}$ & $\begin{array}{l}\text { Utilising resources from other departments } \\
\text { within the same organisation that may be idle or } \\
\text { unused }\end{array}$ & & \\
\hline $\begin{array}{l}\text { Financial } \\
\text { bootstrapping } \\
\text { (Kariv and } \\
\text { Coleman, } \\
\text { 2015) }\end{array}$ & $\begin{array}{l}\text { Utilising easy-access, small-scale financial } \\
\text { resources, rather than those from formal } \\
\text { financial institutions, to minimise the difficulties } \\
\text { in acquiring resources }\end{array}$ & $\begin{array}{l}\text { Easy access, flexible, low cost both to recipients } \\
\text { but also to lender, as the creditability can more } \\
\text { easily established through informal channels. }\end{array}$ & $\begin{array}{l}\text { Such finance is often small in scale, less reliable, } \\
\text { and may come with social baggage hinder the } \\
\text { autonomy of the borrowers. }\end{array}$ \\
\hline $\begin{array}{l}\text { Resource } \\
\text { hijacking } \\
\text { (Stritar, 2012) }\end{array}$ & $\begin{array}{l}\text { Where entrepreneurs take advantage of } \\
\text { resources controlled by others who do not have } \\
\text { a direct business interest in the venture, to } \\
\text { extend their resource base and develop new } \\
\text { ventures }\end{array}$ & $\begin{array}{l}\text { Almost free and up-to-date - e.g. Stritar (2012) } \\
\text { and Kwong, Tasavori and Cheung (2017) found } \\
\text { the use of customers in the viral marketing as } \\
\text { well as providing them with the latest market } \\
\text { information }\end{array}$ & $\begin{array}{l}\text { There is no certainty consensus for co-creation } \\
\text { may be reached. Its use could damage long term } \\
\text { relation with resource controllers. }\end{array}$ \\
\hline $\begin{array}{l}\text { Localised } \\
\text { (Cheung and } \\
\text { Kwong, 2017) }\end{array}$ & $\begin{array}{l}\text { Refers to the utilisation of informal local } \\
\text { network, such as those from friends, family and } \\
\text { acquaintances }\end{array}$ & $\begin{array}{l}\text { Particularly useful in a confined and resource } \\
\text { poor environment. }\end{array}$ & $\begin{array}{l}\text { Often supress the scale of venture, resulting in low } \\
\text { growth potential }\end{array}$ \\
\hline
\end{tabular}


Table 2. Initial categorisations of bricolage that was used to assess each business episode in the interview

\begin{tabular}{|l|l|}
\hline Nature of bricolage & $\begin{array}{l}\text { This involves the consideration of whether and how the event fulfils the criteria of bricolage outlined in } \\
\text { Baker and Nelson (2005). These criteria were the actions of making do, refusal to be constrained by } \\
\text { limitations, and improvisation. }\end{array}$ \\
\hline $\begin{array}{l}\text { Pre-existing resources and } \\
\text { capabilities utilised }\end{array}$ & $\begin{array}{l}\text { This considers the repertoire of internal resources that was utilised in the event. For this part, we first draw } \\
\text { on the resource domains highlighted in Baker and Nelson (2005) as the basis of our categorisation, but later } \\
\text { also include those which emerged from the findings, for instance, resources acquired from pre-existing } \\
\text { networks. }\end{array}$ \\
\hline External resources utilised & $\begin{array}{l}\text { Similar to Pre-existing resources and capabilities utilised, but considers the resources acquired from } \\
\text { external sources. }\end{array}$ \\
\hline Bricolage outcomes & $\begin{array}{l}\text { This considers the economic outcomes of the event, in terms of size, income and growth. In addition to that, } \\
\text { we also record the subjective feeling of the entrepreneurs, and in particular how satisfied they had been with } \\
\text { the event. In some cases, even though an event may be considered as successful in terms of the economic } \\
\text { outcomes achieved, the entrepreneur is not happy because the outcome is not meeting his/her expectations. }\end{array}$ \\
\hline
\end{tabular}


Table 3. Personal details of each respondents

\begin{tabular}{|c|c|c|c|c|c|}
\hline & $\begin{array}{l}\text { Home } \\
\text { Location }\end{array}$ & $\begin{array}{l}\text { Host } \\
\text { Location }\end{array}$ & Family background & Economic or other activities prior to displacement & Immediate situation after displacement \\
\hline 1 & $\begin{array}{l}\text { Parachinar, } \\
\text { Kurram } \\
\text { Agency }\end{array}$ & Peshawar & $\begin{array}{l}\text { Family of landowners } \\
\text { - shops and markets } \\
\text { in local towns. }\end{array}$ & $\begin{array}{l}\text { Studying high school, while involving in the family } \\
\text { business, mostly management and leadership. }\end{array}$ & $\begin{array}{l}\text { Fled at the peak of conflict, initially supported } \\
\text { by rent back home, but that ceased. Then } \\
\text { supported by the family network in an Arab } \\
\text { country }\end{array}$ \\
\hline 2 & $\begin{array}{l}\text { Miramshah, } \\
\text { North } \\
\text { Waziristan }\end{array}$ & Bannu & Father as civil servants & $\begin{array}{l}\text { Ran a large computer shop - using Carol draw, inpage, } \\
\text { and adobe, focusing on photoshop, implement art } \\
\text { work design, composing posters, advertisement in the } \\
\text { local computer market. Had 10-15 apprentices (look at } \\
\text { advert of Carol draw, inpage and adobe office and } \\
\text { their art, composing and printing functions) }\end{array}$ & $\begin{array}{l}\text { Fled at the peak of conflict, worked for NGOs } \\
\text { as data entry volunteers for } 6 \text { months, then } \\
\text { took on a paid data entry clerk position. }\end{array}$ \\
\hline 3 & $\begin{array}{l}\text { Tirah, } \\
\text { Orakzai } \\
\text { Agency }\end{array}$ & $\begin{array}{l}\text { Bara, near } \\
\text { Pesahwar }\end{array}$ & $\begin{array}{l}\text { Family owned } \\
\text { processing tool shop, } \\
\text { a marble processing } \\
\text { workshop, and a farm }\end{array}$ & $\begin{array}{l}\text { Studying high school, while involving in the shop as } \\
\text { apprentice trained by his father, involved in the } \\
\text { management and leadership within the stores. }\end{array}$ & $\begin{array}{l}\text { Fled before peak of conflict, but was unable to } \\
\text { take possessions as must not let others know } \\
\text { they were fleeing. Approached families and } \\
\text { friends but none could help }\end{array}$ \\
\hline 4 & $\begin{array}{l}\text { Miramshah, } \\
\text { North } \\
\text { Waziristan }\end{array}$ & Bannu & $\begin{array}{l}\text { Unknown as fairly old } \\
\text { age }\end{array}$ & $\begin{array}{l}\text { Ran a general store, then turned it into a carpentry } \\
\text { shop, as this is his personal interest since school years. } \\
\text { He specialised in bespoke furniture as well as home } \\
\text { furniture such as chairs, beds and tables. }\end{array}$ & $\begin{array}{l}\text { Fled at the peak of conflict, worked as a } \\
\text { volunteer for a NGO in order to be close to } \\
\text { reliefs and supports }\end{array}$ \\
\hline 5 & $\begin{array}{l}\text { A village in } \\
\text { Orakzai } \\
\text { Agency }\end{array}$ & Kohat & Unknown & $\begin{array}{l}\text { Ran a cloths store with cloths that he bought in from } \\
\text { different suppliers in return for a commission. While } \\
\text { doing so, he developed an interest in sewing and } \\
\text { tailoring, and sell suits that he made by himself using } \\
\text { the cloths, therefore charging commission from the } \\
\text { suppliers and tailoring service from the customers. }\end{array}$ & $\begin{array}{l}\text { Feld at the peak of conflict, as he goods kept } \\
\text { getting stolen and lost through transportation. } \\
\text { Lived in relative's home, repaid them with food } \\
\text { through selling possessions and business stocks }\end{array}$ \\
\hline 6 & $\begin{array}{l}\text { A village in } \\
\text { Orakzai } \\
\text { Agency }\end{array}$ & Kohat & $\begin{array}{l}\text { Unknown as fairly old } \\
\text { age }\end{array}$ & $\begin{array}{l}\text { Ran an electrical store selling small electrical items } \\
\text { bought from Peshawar. Also owned his own cattle and } \\
\text { land }\end{array}$ & $\begin{array}{l}\text { Fled in a haste and was unable to carry } \\
\text { anything. Since they could not afford } \\
\text { transportation, they had to walk } 5 \text { hours on } \\
\text { foot to catch public transportation away. } \\
\text { Worked as a daily wage worker and struggled }\end{array}$ \\
\hline
\end{tabular}




\begin{tabular}{|l|l|l|l|l|}
\hline & & & & $\begin{array}{l}\text { to receive any relief supports from the } \\
\text { government. Could not earn enough to feed his } \\
\text { family. }\end{array}$ \\
\hline
\end{tabular}


Table 4. Data Structure

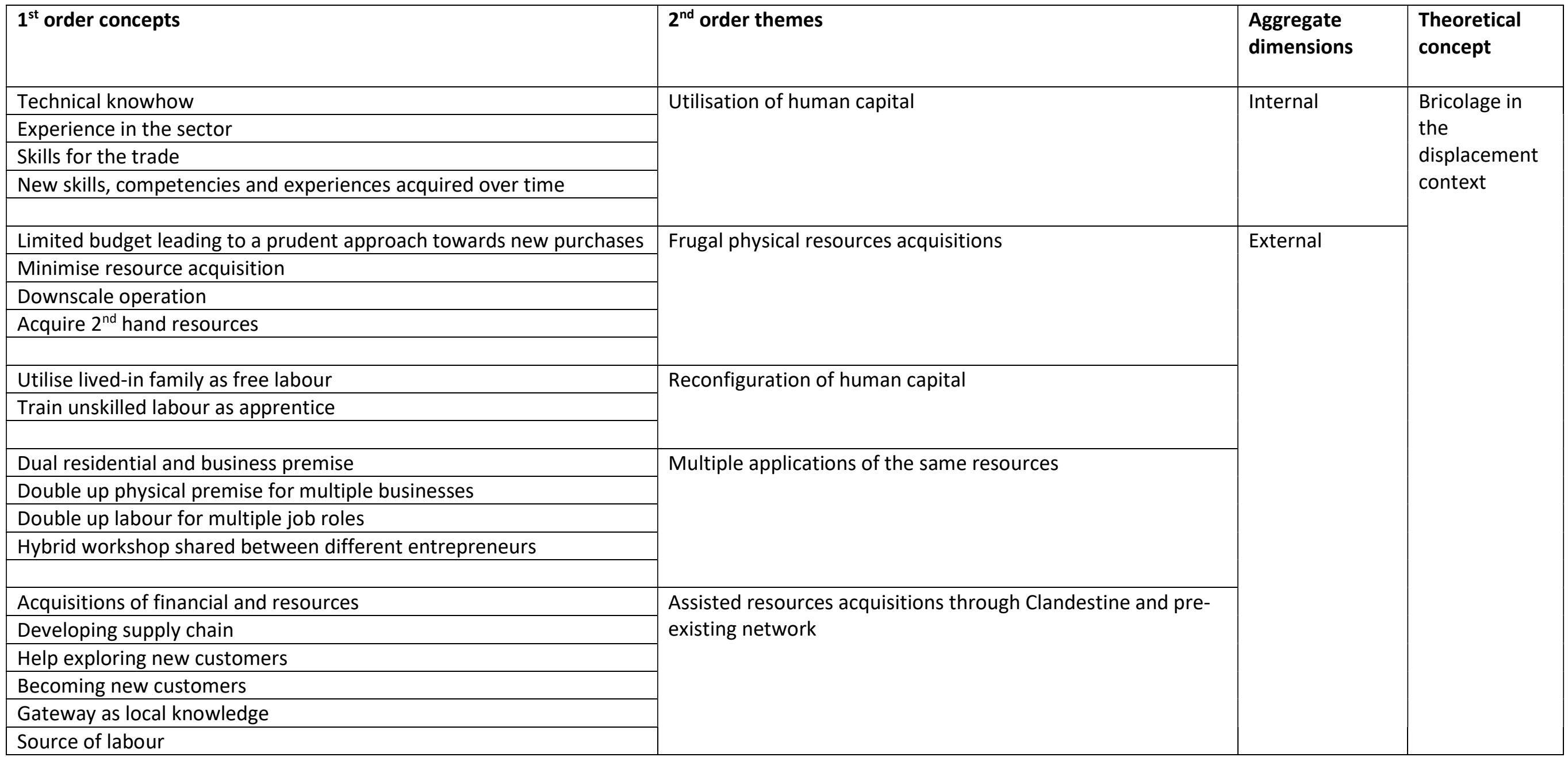


Appendix 1. Entrepreneurship activities amongst the displaced entrepreneurs

\begin{tabular}{|c|c|c|c|c|c|}
\hline & $\begin{array}{l}\text { Nature of bricolage and rationales behind } \\
\text { the opportunity and demand }\end{array}$ & $\begin{array}{l}\text { Utilisations of pre-existing } \\
\text { resources }\end{array}$ & $\begin{array}{l}\text { Utilisations of newly } \\
\text { acquired resources }\end{array}$ & Utilisation of pre-existing network & $\begin{array}{l}\text { Perceived } \\
\text { Outcomes }\end{array}$ \\
\hline \multicolumn{6}{|c|}{ Interviewee 1} \\
\hline V1.1 & $\begin{array}{l}\text { Rented 3-4 rooms and sublet them to } \\
\text { student lodgers, while living there at the } \\
\text { same time. } \\
\text { Rationale: Schools destroyed in home town, } \\
\text { families sent their children to study in host }\end{array}$ & $\begin{array}{l}\text { knowledge of running } \\
\text { properties as a landlord }\end{array}$ & $\begin{array}{l}\text { rental property which } \\
\text { they sublet to new } \\
\text { arrivals }\end{array}$ & $\begin{array}{l}\text { Finance: a friend from a western country } \\
\text { offered money } \\
\text { Agent for lodgers: clan members back } \\
\text { home find suitable lodgers } \\
\text { Labour: lived in relatives as labour }\end{array}$ & $\begin{array}{l}\text { Self- } \\
\text { subsistent }\end{array}$ \\
\hline \multicolumn{6}{|c|}{ Interviewee 2} \\
\hline V2.1 & $\begin{array}{l}\text { Print shop focusing on the production of } \\
\text { professional student ID cards } \\
\text { Rationale: Noted little prior awareness of } \\
\text { such service, approached schools and } \\
\text { successfully gained contracts }\end{array}$ & $\begin{array}{l}\text { Previous experience in owning } \\
\text { and running a computer store }\end{array}$ & $\begin{array}{l}\text { Rental property as } \\
\text { store } \\
\text { Acquire one computer, } \\
\text { printer, scanner, and } \\
\text { tables }\end{array}$ & $\begin{array}{l}\text { Finance: obtain a small loan from uncle } \\
\text { Labour: friends helped out, later also } \\
\text { employed from the clan } \\
\text { Local info: help find a good store }\end{array}$ & $\begin{array}{l}\text { Some } \\
\text { profit }\end{array}$ \\
\hline V2.2 & $\begin{array}{l}\text { Repair for computer-related equipment and } \\
\text { hardware, such as printers and CPU, } \\
\text { alongside V } 2.1 \\
\text { Rationale: Note market demand for these } \\
\text { products }\end{array}$ & $\begin{array}{l}\text { Space in the existing store and } \\
\text { equipment from V2.1 } \\
10 \text { years experiences of } \\
\text { handling computer/hardware }\end{array}$ & None & None & $\begin{array}{l}\text { Additional } \\
\text { income }\end{array}$ \\
\hline V2.3 & $\begin{array}{l}\text { Selling of mobile and charging to download } \\
\text { music for mobiles alongside V } 2.1 \\
\underline{\text { Rationale: Note market demand for these }} \\
\text { products }\end{array}$ & $\begin{array}{l}\text { Computer literacy, space in the } \\
\text { existing store and equipment } \\
\text { from V2.1 } \\
\text { Local market knowledge }\end{array}$ & None & None & $\begin{array}{l}\text { Additional } \\
\text { income }\end{array}$ \\
\hline $\begin{array}{l}\text { V2.4 } \\
\text { (in } \\
\text { plan) }\end{array}$ & Computing academy for school children & Computer literacy & Physical building & $\begin{array}{l}\text { Network: contacts with schools and } \\
\text { school principals }\end{array}$ & $\begin{array}{l}\text { Potential } \\
\text { additional } \\
\text { income }\end{array}$ \\
\hline
\end{tabular}




\begin{tabular}{|c|c|c|c|c|c|}
\hline & $\begin{array}{l}\text { Rationale: Note lack of computer literacy } \\
\text { that can be crucial for different work, and } \\
\text { wanted to help improve computer literacy }\end{array}$ & $\begin{array}{l}\text { Previous experience in training } \\
\text { apprentices in groups, some } \\
\text { illiterate }\end{array}$ & $\begin{array}{l}\text { Additional computer, } \\
\text { hardware and software }\end{array}$ & & $\begin{array}{l}\text { plus social } \\
\text { objective }\end{array}$ \\
\hline \multicolumn{6}{|c|}{ Interviewee 3} \\
\hline V3.1 & $\begin{array}{l}\text { Set up a wholesale business buying } \\
\text { processed marbles from local factories and } \\
\text { export them to a neighbouring country. } \\
\text { Rationale: know the line of business }\end{array}$ & $\begin{array}{l}\text { Pre-existing specialised skills } \\
\text { and knowledge of marble and } \\
\text { marble processing. } \\
\text { Pre-existing market knowledge }\end{array}$ & $\begin{array}{l}\text { Acquired a small rental } \\
\text { store }\end{array}$ & $\begin{array}{l}\text { Finance: from a relative } \\
\text { Export: established trade network from } \\
\text { neighbouring countries } \\
\text { Customers: clan members from the same } \\
\text { region }\end{array}$ & $\begin{array}{l}\text { Self- } \\
\text { subsistent }\end{array}$ \\
\hline V3.2 & $\begin{array}{l}\text { Set up a small marble processing factory } \\
\text { Rationale: move to the more profitable part } \\
\text { of the supply chain }\end{array}$ & $\begin{array}{l}\text { Specialist skills and market } \\
\text { knowledge from V3.1 } \\
\text { Internal finance }\end{array}$ & $\begin{array}{l}\text { Acquired a small rental } \\
\text { factory } \\
\text { Second hand machines }\end{array}$ & $\begin{array}{l}\text { Supplier: Marble suppliers acquainted } \\
\text { with in V3.1 }\end{array}$ & Profitable \\
\hline V3.3 & $\begin{array}{l}\text { Expansion not bricolage. Establish a larger } \\
\text { marble processing factory }\end{array}$ & $\begin{array}{l}\text { Same as above } \\
\text { Internal finance }\end{array}$ & $\begin{array}{l}\text { Larger factory and } \\
\text { newer machines }\end{array}$ & Same as above & Lucrative \\
\hline V3.4 & $\begin{array}{l}\text { Set up an international retail outlet in a } \\
\text { neighbouring country } \\
\text { Rationale: expansion }\end{array}$ & $\begin{array}{l}\text { Specialist skills and market } \\
\text { knowledge from V3.1 } \\
\text { Internal finance }\end{array}$ & $\begin{array}{l}\text { Acquired a new retail } \\
\text { store in a neighbouring } \\
\text { country }\end{array}$ & $\begin{array}{l}\text { Customers: established from previous } \\
\text { exporting endeavour V3.1 }\end{array}$ & Profitable \\
\hline \multicolumn{6}{|c|}{ Interviewee 4} \\
\hline V4.1 & $\begin{array}{l}\text { Set up a hybrid carpentry/ metal repair work } \\
\text { workshop }\end{array}$ & $\begin{array}{l}\text { Pre-existing specialised skill as } \\
\text { carpenter } \\
\text { Relative's pre-existing } \\
\text { specialised skill as car } \\
\text { mechanics specialising in car } \\
\text { dents. }\end{array}$ & $\begin{array}{l}\text { Acquired a small rental } \\
\text { workshop } \\
\text { Used, hand tools } \\
\text { acquired cheaply } \\
\text { locally }\end{array}$ & $\begin{array}{l}\text { Collaboration: joint force with his relative } \\
\text { to share costs } \\
\text { Finance: a son working in an Arabic } \\
\text { country as driver } \\
\frac{\text { Supplier: wood suppliers that they had }}{\text { prior to displacement continued to }} \\
\text { supply them wood }\end{array}$ & $\begin{array}{l}\text { Self- } \\
\text { subsistent }\end{array}$ \\
\hline V4.2 & $\begin{array}{l}\text { Expansion not bricolage. Set up a carpentry } \\
\text { workshop } \\
\text { Rationale: offer autonomy/ independence }\end{array}$ & $\begin{array}{l}\text { Specialist skills and market } \\
\text { knowledge from V4.1 } \\
\text { Internal finance }\end{array}$ & $\begin{array}{l}\text { A new store } \\
\text { Newer tools /machines }\end{array}$ & $\begin{array}{l}\text { Same supplier as above } \\
\text { Customers: customers from their own } \\
\text { clan }\end{array}$ & Profitable \\
\hline
\end{tabular}




\begin{tabular}{|c|c|c|c|c|c|}
\hline \multicolumn{6}{|c|}{ Interviewee 5} \\
\hline 5.1 & $\begin{array}{l}\text { Hawking personal possessions and stocks } \\
\text { from previous venture prior to war }\end{array}$ & $\begin{array}{l}\text { Existing stocks from prior to } \\
\text { conflict }\end{array}$ & None & None & $\begin{array}{l}\text { Self- } \\
\text { subsistent }\end{array}$ \\
\hline 5.2 & $\begin{array}{l}\text { Open up a clothing store for clothes sew by } \\
\text { himself. } \\
\text { Rationale: necessity push as personal } \\
\text { possessions and remaining stocks ran out }\end{array}$ & $\begin{array}{l}\text { Previous experience running a } \\
\text { clothing store } \\
\text { Pre-existing tailoring skill } \\
\text { Sewing machine brought from } \\
\text { home }\end{array}$ & None & $\begin{array}{l}\text { Labour: family members as labour } \\
\text { Customers: were people who they dealt } \\
\text { with in their previous haulage business }\end{array}$ & $\begin{array}{l}\text { Financially } \\
\text { sustainable }\end{array}$ \\
\hline $\begin{array}{l}5.3 \\
\text { (in } \\
\text { plan) }\end{array}$ & $\begin{array}{l}\text { Open up a pharmaceutical business } \\
\text { Rationale: Optimisation not bricolage }\end{array}$ & $\begin{array}{l}\text { Good command of English } \\
\text { acquired from education } \\
\text { Personal savings }\end{array}$ & $\begin{array}{l}\text { External finance from } \\
\text { formal financial } \\
\text { institutions }\end{array}$ & $\begin{array}{l}\text { Finance: family could offer financial } \\
\text { support }\end{array}$ & $\begin{array}{l}\text { Expected } \\
\text { to be } \\
\text { profitable }\end{array}$ \\
\hline \multicolumn{6}{|c|}{ Interviewee 6} \\
\hline 6.1 & $\begin{array}{l}\text { Selling solar panels, solar fans and coolers } \\
\text { Rationale: recognise demand of solar items } \\
\text { and that supply is not saturated }\end{array}$ & $\begin{array}{l}\text { Knowledge of electrical items } \\
\text { from pre-conflict venture }\end{array}$ & $\begin{array}{l}\text { External finance from } \\
\text { clandestine network }\end{array}$ & $\begin{array}{l}\text { Finance: Clandestine network offering } \\
\text { start up finance } \\
\text { Suppliers: suppliers from pre-conflict } \\
\text { venture in Peshawar } \\
\text { Customers: Clandestine customers and } \\
\text { those from previous business }\end{array}$ & $\begin{array}{l}\text { Financially } \\
\text { sustainable }\end{array}$ \\
\hline 6.2 & $\begin{array}{l}\text { Assembling and repair solar and electrical } \\
\text { items } \\
\text { Rationale: recognise demand while involving } \\
\text { in the selling of solar panels in } 6.1\end{array}$ & $\begin{array}{l}\text { Assembling and repair skills } \\
\text { self-taught from pre-conflict } \\
\text { venture }\end{array}$ & None & $\begin{array}{l}\text { Customers: Clandestine customers and } \\
\text { those from previous business }\end{array}$ & $\begin{array}{l}\text { Additional } \\
\text { income } \\
\text { and service }\end{array}$ \\
\hline
\end{tabular}


Figure 1. Map of the region (Developed from https://commons.wikimedia.org/wiki/File:NWFP FATA.svg. Accessed on 14 Oct 2017)

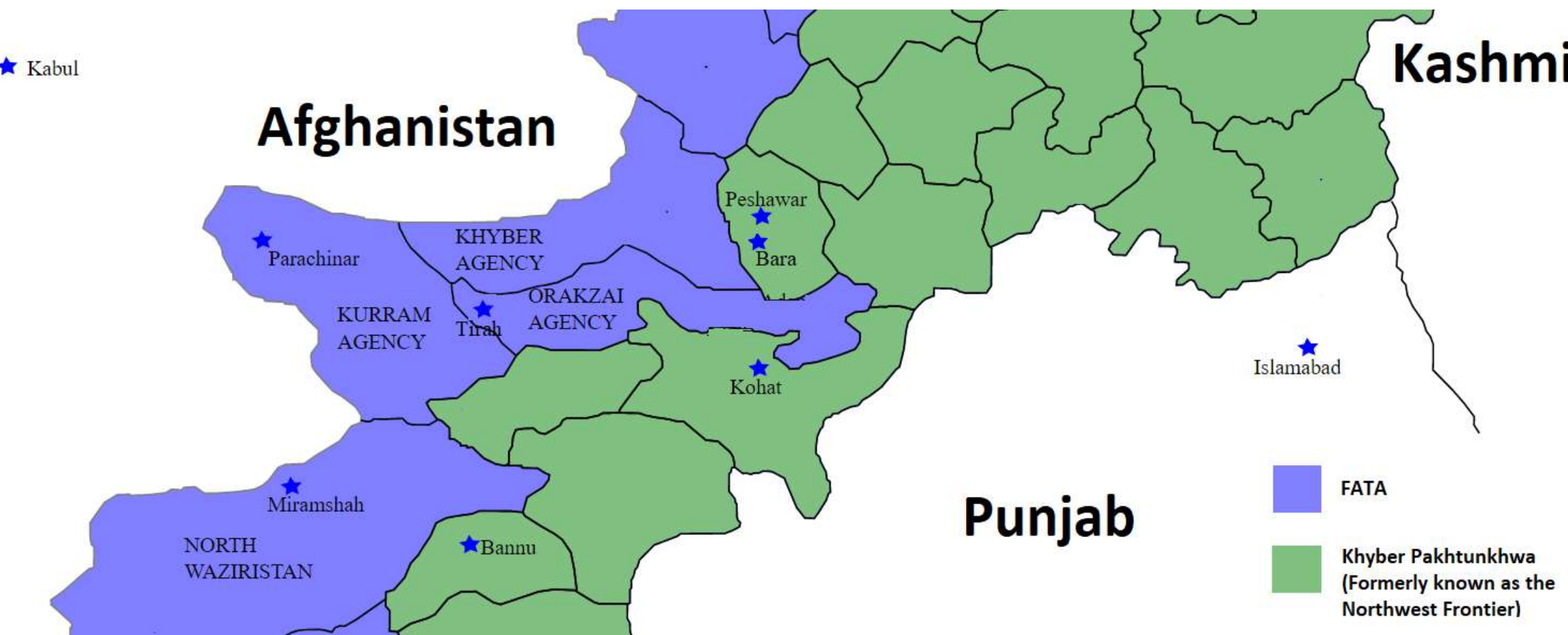

Peshawar district Peshawar is the capital of the Khyber Pakhtunkhwa (KP) province, with a multi-ethnic population of around $2 \mathrm{~m}$. It is connected to Afghanistan through the historic Khyber Pass. Trade between Afghanistan and Pakistan mostly takes place here.

Kohat district

Kohat is the major city of the district (near $1 \mathrm{~m}$ ) inhabited mostly by the Bangash and Hindko who speak Pashto and Hindko respectively. Recently, the mix of population has changed since it was considered as a safe haven for the nearby troubled areas.

Bara town Bara is a small town (pop around 35,000) $15 \mathrm{~km}$ away from Peshawar. It situated on a main passageway (Bara Road) connecting Peshawar to the FATA. It is also connected to Kohat. It is known that illegal trade with Afghanistan normally takes place in its market.

Bannu district Bannu is in the southern part of KP (pop 1.2m). Banuchi speaks a dialect of Pashto, as with most tribes in the Waziristan. The easy access from Waziristan mean that most IDP travelled through Bannu as the first port of call.

Orakzai agency Orakzai is one of the FATA (pop $0.45 \mathrm{~m}$ ) comprising of predominantly Pashtun and 18 subsidiary tribes. The Tirah valley is flanked by mountain ranges 6,000 to 7,000 feet high and many parts can be difficult to access. 
Kurram agency

North Waziristan agency
Parachinar is the administrative headquarter of Kurram Agency, and the largest city of the FATA (pop 0.7m). It is the closest point in Pakistan to Kabul as it borders Afghanistan.

Waziristan is a large mountainous region with a disperse population. Its administrative HQ is Miramshah (pop 0.36m). The region is inhibited by Wazirs, who speaks Pashto in Wazirs dialect and with a warrior reputation. 